\title{
Competencies for e-Instructors: How to Qualify and Guarantee Sustainability
}

\author{
Yasemin Gulbahar \\ Ankara University, Turkey \\ Filiz Kalelioglu \\ Baskent University, Turkey
}

\begin{abstract}
e-Learning is becoming more popular than ever with the advent of new technologies and new inventions for teaching and learning. Hence, competent e-Instructors are key to successful e-Learning implementations and they should have the appropriate skills and experience for the effective implementation of e-Learning and blended learning. eInstructors are instructors who might well be very experienced in teaching-learning contexts and even possess a high level of technology literacy. However, being an experienced instructor and possessing advanced skills of using technology does not necessarily lead to an instructor becoming an effective e-instructor. The purpose of this article is to understand which competencies are needed to be an effective e-Instructor and how can we help individuals to acquire these skills? In order to answer these questions, a broad literature review will help understand what the accepted competencies are for e-Instructors, any existing strategies for professional development, possible challenges to this process and any known solutions. On-going professional development is essential for being a role model for learners and for effective usage of technological environments. Based on the facts and research results in parallel with the advancement in the technological world as instructors, they should keep themselves up-to-date according to e-competencies defined for instructors and continue searching to make this process easier for both instructors and learners to become more effective. Consequently, future research studies can focus on the strategies and methods for self-determined, self-paced and personalised instruction to cope with the e-instructor competencies.
\end{abstract}

Keywords: e-competency; e-instructor; e-instructor certification; e-instructor competency

\section{Introduction}

e-Learning is becoming more popular than ever with the advent of new technologies and new inventions for teaching and learning, especially in the case of higher education in e-Learning and blended learning. Hence, competent e-Instructors are key to successful e-Learning implementations and they should have the appropriate skills and experience for the effective implementation of e-Learning and Blended Learning. In general, every instructor first becomes an Instructor then becomes an e-Instructor. Being a good e-Instructor means possessing more knowledge and skills about instructional technologies and even positive attitudes towards technological tools and processes. Thus, e-Instructors should be using information and communication technologies (ICT) effectively in all the phases of teaching, facilitating and assessing learner work. Although many instructors are highly qualified teachers with many 
years of experience, they acquire these valuable skills and experience based on their various instructional implementations with different groups, content and methods.

The question here is whether or not they have to be successful in adapting the use of different instructional technologies into their teaching-learning processes. At first sight, it seems that being technology-literate may solve this problem however; it is not just the involvement of technology in educational contexts, it is the transformation of what is already known from face-to-face environments into virtual settings, combined with effective technology use and virtual experience. This process could be quite easy for technology-literate instructors, but what about those who are not technologically-literate? What could be done for these instructors to help them become experienced virtual instructors? The purpose of this paper is to understand which competencies are needed to be an effective e-Instructor and how can we help individuals to acquire these skills?

In order to answer these questions, a broad literature review will help to understand what the accepted competencies are for e-Instructors, any existing strategies for professional development, possible challenges to this process and any known solutions. Based on this evidence, researchers will try to provide a model for both instructors and institutions to provide adequate and high quality solutions. Hence, it is expected that application of the proposed model will help Instructors to gain the necessary skills and capabilities to use instructional technologies innovatively and efficiently to meet the needs of their e-learners.

\section{What Are Competencies? Why do we need them?}

Spector and de la Teja (2001) defined competence as the "...state of being well qualified to perform an activity, task or job function" and competency as "... the way that a state of competence can be demonstrated to the relevant community" (p. 2). On the other hand, The International Board of Standards for Training, Performance and Instruction (IBSTPI) (www.ibstpi.org) defined a competency as "a knowledge, skill, or attitude that enables one to effectively perform the activities of a given occupation or function to the standards expected in employment".

As a result of the changes of the focus in teaching approaches, the learning products of these approaches are known by different names, such as goals, objectives and learning outcomes. In this case, the questions may come to mind where competency stands and why we need these terms. For the first question, learning objectives or outcomes are more specific and measurable statements which define what the learner will do to accomplish the course. On the other hand, competencies are broader and more comprehensive than learning outcomes or objectives because they cover many learning objectives or outcomes (Figure 1). Hartel and Foegeding, (2004) defined these terms by noting the difference. According to the authors, "outcome is s very specific statement that describes exactly what a student will be able to do in some measurable way" while "competency is a general statement detailing the desired knowledge and skills of student graduating from our course or program" (p. 69). According to the Learning Outcomes Handbook of University of Wisconsin, La Crosse (2009), a learning objective gives information about "what we hope our students will learn"; whereas a learning outcome describes "what our students actually learn and can be observed, and assessed against specific criteria" (p. 2). 


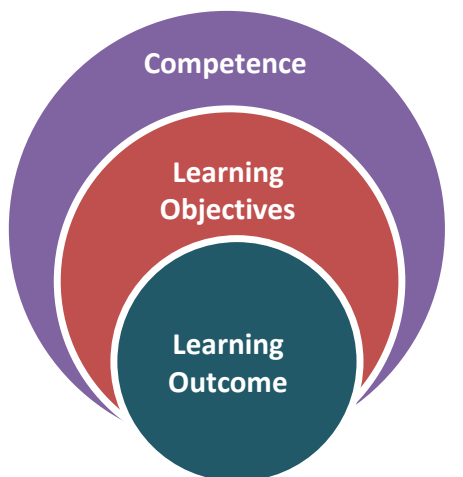

Figure 1. Relationship between Learning Outcome, Objective and Competence
Moreover, Hartel and Foegeding, (2004) showed an example depicting the relationship among competence, learning objective and learning outcome from the food engineering department. In the broadest sense, competence can be seen as an umbrella covering both learning objectives and learning outcomes. Hence, a similar example from education field may be seen in Figure 2.

\section{Competence}

The learner should be able to use instructional design principals and models for a given educational context.

\section{لII}

\section{Learning Objectives}

- Understand aim and scope of instructional design for instructional systems.

- Analyze and evaluate appropriate use of instructional models for teaching-learning processes.

\section{Vt v}

\section{Learning Outcomes}

- Describe the general phases of various instructional models.

- Draw a diagram including samples to demonstrate implementation of the instructional models for instructional problems.

- Solve instructional problems associated with difficulties in learning.

- Design and solve various instructional problems for performance improvement, including complex training needs of various groups who have different prior knowledge and personal characteristic, according to the chosen instructional model.

- Evaluate the implemented instructional design for a training program.

Figure 2. Relationship between Competence, Learning Objective and Outcome

One of the answers to the second question concerns measurement and evaluation, as identified by Hartel and Foegeding (2004) - "learning outcomes are the basis for an assessment program that focuses on what a student can do either upon completion of a course or upon graduation from a program" (Hartel and Foegeding, 2004, p. 69). Actually, there is a list of reasons why we need the description of what a student will do in the Learning Outcomes Handbook of University of Wisconsin, La Crosse (2009). According to the list, learning outcomes assure that learning is occurring in an objective, measurable way and supporting the 
university's mission, motivates students to participate in educational activities, and helps to describe the improvement in learning and constitute a common basis for all departments.

Competencies are also very popular in the workplace. Therefore, both in workplace and educational contexts, learners, teachers and curriculum all have defined competencies. Globally disseminated, competencies have become highly valued by educators and educational institutions throughout the world.

\section{Who are Online Instructors or e-Instructors?}

E-Instructors are instructors who might well be very experienced in teaching-learning contexts and even possess a high level of technology literacy. However, being an experienced instructor and possessing advanced skills of using technology does not necessarily lead to an instructor becoming an effective e-instructor. The first reason is that the instructor may not be ready for the online journey. Online instructors have to be ready to help and effectively communicate with students without the advantages of communicating through face-to-face interaction. Moreover, instructors have to improve their e-management skills, adapt their teaching methods to the online environment, learn to manage different types of discussion, offer students authentic, structured online activities, design instructional materials, and be available $24 \times 7$ in order to answer the e-students and give feedback for the students' assignments. As online learning environments continue to evolve, both teachers and students need to adapt to make the most of the opportunities. On-going professional development is essential for being a role model for learners and for effective usage of technological environments.

\section{Competencies for Online Instructors or e-Instructors}

As also mentioned by Davis and his colleagues (2007), online teachers, namely e-instructors, should possess more qualities and skills, especially in terms of technological innovations, than a traditional teacher does. These qualities and skills are systematically constructing the ecompetencies of the teachers who want to teach online. Guasch, Alvarez and Espasa (2010) used competency as an operative concept in their studies which means "...a system of complex actions including the knowledge, abilities and attitudes required for the successful completion of tasks" (p. 200). According to the results of Coppola, Hiltz, and Rotter's study (2002), the role of the teacher has changed from subject expert to performance coach. In online learning, cognitive, affective and managerial were three specific roles of the teachers. Moreover, Williams (2003) categorised the e-competencies of teachers as communication and interaction, instruction and learning, management and administration, use of technology. Smith (2005) identified and described 51 e-competencies for teachers. These e-competencies are categorised into three main headings: competencies needed before the course, competencies needed during the course and competencies needed after the course.

Berge (1995) described the role of the online instructor as "facilitator" whose main role is modelling effective teaching and delivering the e-content that should be based on four dimensions as: pedagogical, social, managerial, and technical. In this categorisation, the pedagogical dimension refers to subject expertise, coaching and assessing; the social dimension refers to interpersonal, communication and facilitation skills; the managerial dimension refers to administrative and leadership skills; and finally, the technical dimension refers to technological literacy. 
Guasch, Alvarez and Espasa (2010) identified teachers' e-competencies from literature as design/planning function, social function, instructive function, technological domain, and management domain. To summarise this categorisation, teachers should plan the design of instruction from objectives to evaluation of the lesson, should improve their relationship and communicate with their students, should instruct and facilitate learning in a deep, complex and critical manner, should use the necessary technology, and should organise and modify the online process. Misra (2010) proposed a strategy list for teachers that will teach online. According to the list, educational institutions should establish e-technologies labs, offer peer supported e-training, develop e-bonding among teachers, ensure e-mediated teaching, promote e-sharing among teachers, and reward e-activities of teachers. To summarise the categorisation of these competencies, a table from this literature review is shown below.

Table 1. Categorization of Competencies

\begin{tabular}{ll}
\hline Researcher(s) & Categories \\
\hline Berge (1995) & $\begin{array}{l}\text { Pedagogical dimension (subject expertise, coaching and assessing); } \\
\text { social dimension (interpersonal, communication and facilitation } \\
\text { skills); managerial dimension (administrative and leadership skills); } \\
\text { technical dimension (technological literacy) }\end{array}$ \\
Richey et al. (2001) & $\begin{array}{l}\text { Professional foundation; planning and analysis; design and } \\
\text { development; implementation and management }\end{array}$ \\
Williams (2003) & $\begin{array}{l}\text { Communication and interaction; instruction and learning; } \\
\text { management and administration; use of technology. }\end{array}$ \\
Dennis et al. (2004) & $\begin{array}{l}\text { Pedagogical; communicational; discipline experts; technological } \\
\text { Klein et al. (2004) }\end{array}$ \\
$\begin{array}{l}\text { Professional foundations (communications, professional } \\
\text { development, law and ethics, and credibility); planning and } \\
\text { preparation; instructional methods and strategies (motivating, } \\
\text { presenting, facilitating, questioning, clarifying and correcting, skill } \\
\text { retention and transfer); assessment and evaluation; management } \\
\text { (managing the environment and managing appropriate technology } \\
\text { use) } \\
\text { Administrative; design; facilitation; evaluation; technical } \\
\text { Competencies needed before the course; competencies needed } \\
\text { during the course and competencies needed after the course. } \\
\text { Design/planning function, social function, instructive function, } \\
\text { technological domain, and management domain. }\end{array}$ \\
$\begin{array}{l}\text { Shank (2004) } \\
\text { Espasa (2010) }\end{array}$ \\
\hline
\end{tabular}

\section{About Certification in Higher Education}

There are many universities like Virginia Tech University, North Carolina State University, University of Michigan, University of New Mexico, University of Wisconsin, Ferris State University and institutions like ASTD, Sloan-C who provide certificate programmes under different headings such as online instructor, online teaching, blended learning and e-learning certificate programmes at both basic and advanced levels besides providing various levels of certification. The programmes offer different aspects of teaching processes including; online 
teaching and pedagogy, Learning/Course management systems, training in multimedia products pertinent to their proposed course material development and delivery.

Just to provide some examples, Virginia Tech Institute for Distance and Distributed Learning (IDDL) provides workshops for the Online Certificate Programme and Master Online Certificate Programme, including topics such as; instructional design, course design and development, multimedia development including audio/video production, graphic design, and programming, interaction enhancement, Copyright and Fair Use in Online Courses, Communication: Wikis and Blogs and Overview of Assessment in the Online Classroom (http://www.iddl.vt.edu/ workshops.php). Slightly differently, North Carolina State University McKimmon Center for Extension and Continuing Education provides a Comprehensive Online Instructor Certificate Programme composed of topics like Introduction to Online Teaching, LMS Basics, Intensive Course Development, Copyright Issues, Course Quality Assessment, Introduction to Graphic Design, and Introduction to Web Development (https://onece.ncsu.edu/).

University of Michigan-Fliny Office of Extended Learning also offers an Online Instructor Certificate Programme including LMS Basics, Introduction to Online Teaching, Intensive Course Development, Copyright Issues in Online Teaching, Course Quality Assessment and Social Software beside some more technical issues like audio-visual production and multimedia production (http://www.umflint.edu/oel/OIC.htm). Moreover, University of West Florida Academic Technology Centre provides a Quality Online Instructor Certificate which focuses on the issues of Understanding the QM rubric, Planning your online/blended course, Designing your course in eLearning, Online assessments and Student engagement strategies (http://uwf. edu/atc/Training/QOIC.cfm).

The University Of New Mexico Division Of Continuing Education offers an Online Instructor Certificate as distinct courses for each semester like Facilitating Adult Learning, Instructional Systems Design, Introduction to Online Instruction, Exploring Technologies Used in Online Development and Basics of Online Course Development (http://dce.unm.edu/instruction-andfacilitation-training.htm). As a last example from higher education institutions, University of Wisconsin School of Education provides an E-learning and Online Teaching Graduate Certificate as distinct courses each lasting 8 weeks such as; E-learning for Educators, Assessment in E-learning, Instructional Design for E-learning, and Creating Collaborative Communities in E-learning (http://www.uwstout.edu/soe/profdev/elearningcertificate.cfm).

Other than the higher education institutions a well-known organisation ASTD also offers certificates like Blended Learning Certificate for teaching professionals who design/deliver training and want to adopt blended learning approaches and E-Learning Instructional Design Certificate besides workshops about e-Learning for practitioners new to e-learning technology. SLOAN-C (2012) also offers an Online Teaching Certificate which addresses topics like Quality Online Courses and Teaching, Syllabus and Schedule, Online Learning Communities, Emerging Technologies, Assessment and Evaluation, Usability, \& Copyright and Workload Management.

\section{What is Already Said about Competencies of e-Instructors?}

Davis and his colleagues (2007), proposed a virtual school curriculum having four categories pedagogy, technology, assessment, and virtual classroom management. In this curriculum, teachers are taught different learning approaches including didactic inquiry and problembased learning, several technologies and learning tools including LMS, live videoconference 
system and an audio conferencing system, numerous methods of assessment including reflections, proctored and performance-based tests, and quizzes. Levinsen (2007) offered an in-service online teacher education program having separate, but integrated and interrelated subject domains: technical skills, pedagogical competencies and communicative competencies. In this online teacher education programme, teachers have hands-on activities with technology that will be helpful for their e-learning experience, learn to design e-courses and master communication skills for online environment.

Also, Awouters and Jans (2009) mentioned a postgraduate e-learning course, consisting of four modules: pedagogical-didactical, technical, communication, and project modules. In the pedagogical-didactical module, learning theories related to online learning are covered while in the technical module, all information technologies are studied. In the communication module, e-moderator roles of teachers and side-effects while using e-elements are taught and lastly in the project module, teachers reflect on their skills gained throughout the course. Kelz (2011) mentioned about the teacher training programme in his university; with this course teachers acquire sufficient ICT, pedagogical and social skills covering topics of using LMS, designing and managing online activities, integrating different teaching and learning styles, interacting with students and giving feedback to them. This nationwide "E-Learning Certificate" programme consists of three modules; in module 1, media didactics in teaching such as use of media in teaching, installation and use of e-learning courses in LMS systems and collaborative e-learning are covered, in module 2 media production such as digital photography, e-learning and law, e-learning and web 2.0 are main topics and in module 3 media organisation and e-moderation are described. After completion of three modules within 18 months, an e-learning certificate is awarded to the participants.

\section{Competency Models for Online Teaching/Instructors}

\section{The ASTD Competency Model}

The model offered by ASTD (2013) outlines the latest competencies needed for the training and development profession. This model can be used as a roadmap for the professional development of leaders and practitioners. Foundational competencies and role-specific competencies are two main highlights (Figure 3).

In this model, foundational competencies are business skills, a global mindset, industry knowledge, interpersonal skills, personal skills and technology literacy. For the role-specific competencies, the areas of expertise are change management, performance improvement, instructional design, training delivery, learning technologies, evaluating learning impact, managing learning programmes, integrated talent management, and coaching knowledge management.

In the model, basic competencies cover the knowledge, skills, abilities, and behaviours that are fundamental in most professions for job success. Business skills are defined as being able to analyse requirements and offer solutions, to apply business skills, to reach conclusions, to plan and implement assignments, to think purposefully and to innovate. Global mindset are defined as being able to accommodate cultural differences, to show respect for different points of view, to develop self-awareness, to adapt behaviour to accommodate others, to champion diversity and to leverage diverse contributions. Industry knowledge is defined as being able to 
maintain self professional knowledge, to follow the changes in industry and trends, and to build industry sector knowledge. Interpersonal skills are defined as to being able to build trust, to communicate effectively, to influence stakeholders, to network and partner, and to demonstrate emotional intelligence. Personal skills are defined as being able to demonstrate adaptability, and to model personal development. Technology literacy is defined as being able to demonstrate awareness of technologies and to use technology effectively.

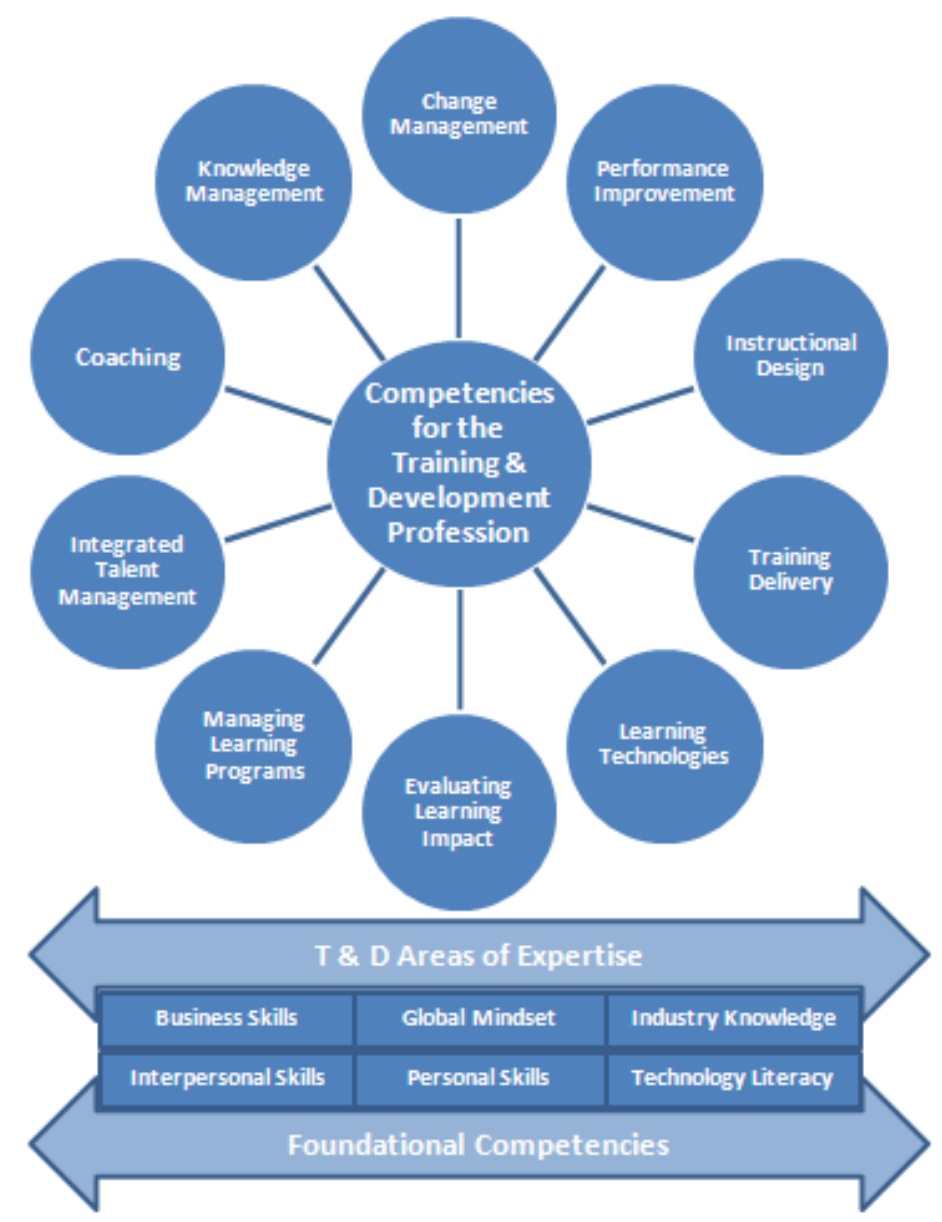

Figure 3. ASTD Competencies for the Training \& Development Profession (http://www.astd.org/Certification/Competency-Model)

T\&D Areas of Expertise are functional competencies that are specific to the training and development profession. Performance improvement refers to apply a systematic process for analysing and addressing human performance gaps. Instructional design refers to the design and development of formal and informal learning solutions using a variety of methods. Training Delivery refers to the delivery of formal and informal learning solutions in a manner that is both engaging and effective. Learning Technologies refers to apply a variety of learning technologies to address specific learning needs. Evaluating learning impact refers to the use of learning metrics and analytics to measure the impact of learning solutions. Managing Learning Programmes refers to the provision of leadership to execute the organisation's people strategy, and implement training projects and activities. Integrated Talent Management refers to the build of an organisation's culture, capability, capacity, and engagement through people 
development strategies. Coaching refers to the application of a systematic process to improve others' ability to set goals, take action, and maximise strengths. Knowledge Management refers to the capture, distribution, and archival of intellectual capital to encourage knowledgesharing and collaboration. Change Management refers to the application of a systematic process to shift individuals, teams, and organisations from their current state to a desired state.

\section{Instructional Competency Model}

The model offered by Al-Hunaiyyan, Al-Sharhan and Al-Sharhan, (2012) defines the latest competencies for e-teachers to ensure they can follow modern developments in terms of educational, technological or behavioural developments. The Instructional Competency Model has six competency aspects; knowledge and cultural, technical and technological, practical, behavioural and social, supervision and planning, and teaching methods and instructional design (Figure 4).

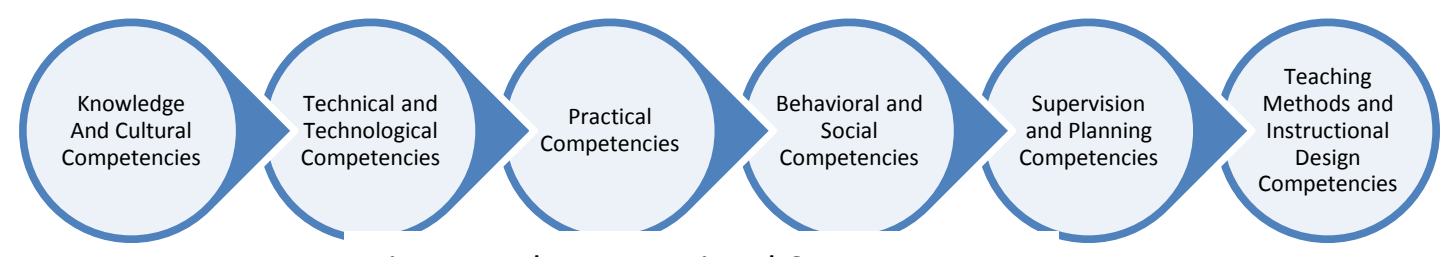

Figure 4. The Instructional Competency

The knowledge and cultural characteristics influence the instructor's personality, instructional design process, teaching methods etc. Moreover, the teacher has to be ready to face these cultural challenges and the large amount of information from different Internet and knowledge sources. Technical and technological competencies mean that instructors have to be capable with not only how to use instructional techniques and tools, but also how to adapt those tools to the courses.

The practical and hands-on competencies require skills and abilities from instructors to use and benefit from technological tools in order to interact with the students. Behavioural and social competencies require skills and abilities from teachers such as positive interaction with learners, to guide them about the ethical use of information, to take into account their individual differences and to encourage students to respect others' rights and thoughts. For the supervision and planning competencies, an instructor has to be capable with the planning, design and development supervision and guidance domains. Teaching methods and instructional design competencies require skills and abilities from the teacher to design instructional, considering every step of instruction.

\section{Media Competence Model for Teachers}

The Media competence model for teachers (Bremer, 2010) covers all three phases of study, practical years, and continuous and advanced professional training of teachers. The model 
focuses on the progressive integration of different competence phases, along with transition profiles. These phases progress with different competencies that begin with the theoretical aspects of online learning, and go on to include technical competencies and covering didactical aspects of instruction (Figure 5).

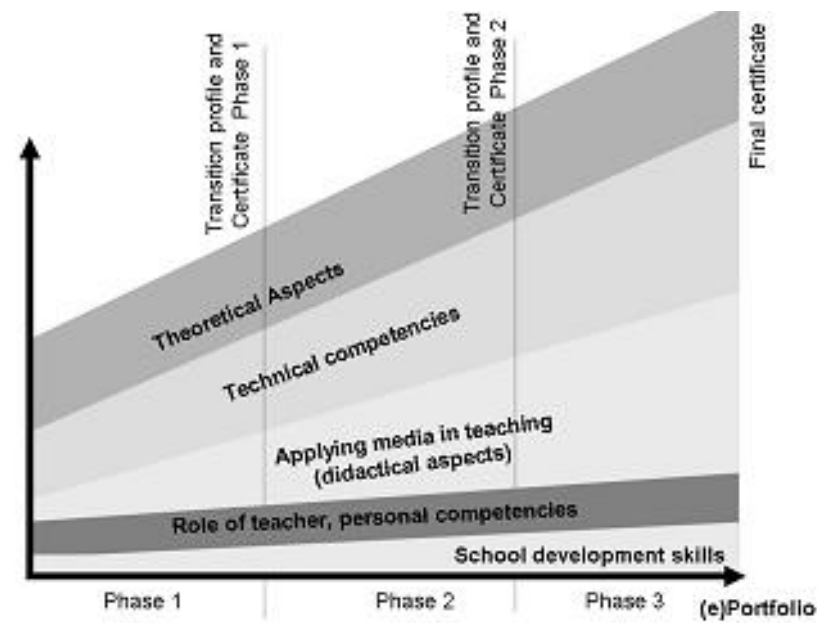

Figure 5. The Media Competency Model

\section{Suggested Curriculum for a Certificate Programme to Donate Tutors with e-Skills}

The Distance Education Centres of many universities coordinate the delivery of the various distance education programmes at the level of vocational, undergraduate and even graduate. In general, universities are offering programmes in different disciplines. Hence, instructors who are expected to teach online have to possess necessary technological and instructional design skills.

Based on a need revealed after several workshops held with the e-Instructors of various distance education programmes provided by Ankara University, and detailed review of literature provided in this article, a certificate programme specifically developed for faculty members was designed. The programme was designed within the context of Pedagogical Content Knowledge (PCK), which was first introduced by Shulman (1986). In this context, pedagogical knowledge deals with how to teach and content knowledge is knowledge about the subject matter. Later, this idea was extended by Mishra and Koehler (2006) with an addition as Technological Pedagogical Content Knowledge (TPCK). Here, technological concepts, together with content knowledge and pedagogical dimensions refer to an instructor's knowledge of how to integrate and make effective use of technology in a curriculum. Hence, the framework for the certificate programme is based on a broad review of literature and web search, in a context of TPACK (Technology, Pedagogy, Content, Knowledge), and learning by doing was the main goal of the programme. Similarly, Barker (2002) said that facilitators and mentors should get together to form an online community of expertise and the content should be delivered to them online. After the success of the first pilot implementation, the Distance Education Centre offered this certificate programme nationally for all faculty members, instructors and teachers, as well as other interested individuals who are expected to use distance education method in their institutions. 
There are many educational institutions and highly respected organisations that provide similar certificate programmes to volunteers. An 80 hour programme composed of fourteen main topics was developed with the programme lasting for three months, with two divisions of 7 six weeks in each.

- Basics of e-Learning (Basic Concepts, Types of e-Learning, Time vs. Place Asynchronous vs. Synchronous, E-Facilitator (changing roles and responsibilities) Learning Environments and Interaction Types)

- Application of Instructional Theories to Online Environments (Behaviourism, Cognitivism, Constructivism, Connectivism, Adult Learning and Self-Regulated Learning)

- Learning and Content Management Systems (Online Learning Communities, EModeration, LMS/CMS Features, Moodle and MOOCS)

- Virtual Classroom Applications and Webinars (Managing Virtual Learning Environments, Adobe Connect and BigBlueButton)

- Instructional Design Issues (Knowledge Management, Learning Goals \& Outcomes, Instructional Planning/Syllabus, Learning Opportunities/Activities and Course Structure)

- Instructional Methods and Techniques (Presentation, Training, Concept Teaching, Collaborative Learning, Problem-based \& Project-based Learning and Discussion)

- Copyright and Ethical Issues, Plagiarism (Copyright, Digital Rights Management, Creative Commons and Plagiarism)

- e-Assessment (Classical Assessment Approaches (tests, essays, matching, fill in the blank etc.) and Alternative Assessment Approaches (webquest, e-portfolio etc.)

- Graphical Design (Graphical Design Principles, Graphical Organizers and Storyboarding)

- Creating Effective Visuals (Posters, Mind Maps, Concept Maps and Infographics)

- Multimedia Content Development (Audio-Visual Content, Narrated presentations and Educational Videos)

- Creating Interactive Applications (Tools for Creating Interactive Application and Interactive Mobil Applications)

- Social Media and Emerging Technologies (Social Networking, Document Sharing, Media Sharing, Collaboration Tools and Blogs \& Microblogs)

- Quality Assurance in e-Learning (Competencies, Usability, Course Evaluation and Satisfaction)

In response to a demand by some e-Instructors to be equipped with up-to-date information, skills and values for effective usage, the e- Instructor certificate programme was introduced. In addition, other instructors who have active roles in e-learning or simply want to support their teaching-learning processes with technology requested this training, and so the certificate programme has been implemented seven times since September 2011, with approximately 240 participants in total. Based on satisfaction surveys, one of the important findings was the raising of awareness among instructors about the context. Most of them are stated that they became aware of what they should learn and they realised which capabilities they should 
develop, and in what areas. Satisfaction level was quite high and the participants declared an interest in gaining a possible advanced certification, focussing on instructional design and econtent creation, including more asynchronous and synchronous learning activities. Obstacles faced during implementation of the programme were mainly due to pedagogical and technical deficiencies.

Thus, the e-Instructor certification programme was a first attempt in Turkey and the results have revealed the necessity and importance of such a training programme for possible eInstructors of all ages. Although there is not a huge demand, it is obvious that there is now a small online community emerging that want to work towards quality in e-Learning.

\section{Discussion and Conclusion}

It is very obvious that instructors from various disciplines should equip themselves with the required e-competencies to teach and assess effectively. As also stated by Al-Salman (2011) "Unlike what has been traditionally required from faculty in academia, distance learning necessitates that online faculty master a number of roles and acquire a specific set of competencies" (p. 12). There are numerous ways and strategies for achieving this goal. Online teaching colleagues have diverse educational backgrounds ranging from different disciplines to different age levels, and it's the same situation all over the world. Anderson (2010) suggested some recommendations for those who will teach online in the future: being a student in an online course; acting as a guest speaker in an online class; listening experiences of an online instructor; attending Professional development activities; using online teaching and Web 2.0 tools are some of these suggestions. In parallel with these suggestions, Guldberg and Pilkington (2007) conducted a study and concluded that their findings "... highlight the need for course tutors generally to think carefully about the pedagogical considerations of their courses and to consider the types of questions that need to be posed in terms of meeting the relevant learning outcomes" (p.69).

Instructors, whether they are experienced in teaching or not, have to adapt themselves to the differences of online teaching, since new innovations in educational technology may be challenging for them. As also stated by Goold, Coldwell \& Craig (2010), "Even experienced teachers require support to continually adapt and improve their skills as the technologies continue to evolve" (p. 714). Moreover, online teaching cannot be successful by simply transforming traditional instruction and its components to online environments. Regarding to this topic, Yar, Asmuni and Silong (2008) stated that both instructors and students may be faced with dramatic shifts while transitioning from traditional implementations to technologybased environments. The researchers also underline the continuous change in this shifting process in terms of technology as well as political and institutional factors.

Another obvious fact is the increasing demand toward online courses from both educational and business institutions, which again raises the question of qualified e-instructors, together with the qualified e-content. On this topic, Barker (2002) stated that "This requirement implies that adequately trained e-tutors are available and that they will be 'equipped' with appropriate skills that will enable them to undertake the tasks that they will be required to perform within an online learning community" (p. 11). Similarly, Goold, Coldwell \& Craig (2010) suggested that proper and continuous professional development opportunities should be provided to all teaching staff to fulfil the premise of becoming effective e-instructors. 
Hence, this adaptation process will be effective and efficient if it is supported by training opportunities together with best practices for implementing those roles (Burkle \& ClevelandInnes, 2013; Al-Salman, 2011; Liu, Bonk, Magiuka, Lee, \& Su, 2005). Similarly, Queiroz (2003) said that "Each medium requires different approaches to be used. The teachers should be trained to work online and "instructed" so they can achieve their pedagogical goals in a more effective, creative and innovative way when using a Virtual Learning Environment (VLE)".

Palloff and Pratt (2011) envisioned the best system for online faculty development as a comprehensive system that has three dimensions, namely faculty development, selfdevelopment and institutional support. The researchers concluded that "The resultant excitement about learning helps stimulate new creative approaches to online teaching and demonstrates that there can be and is, in fact, an excellent online instructor" (p. 115). Hence, based on these facts and research results in parallel with the advancement in the technological world as instructors, we should keep ourselves up-to-date according to e-competencies defined for instructors and continue searching to make this process easier for both instructors and learners to become more effective and efficient. Consequently, future research studies can focus on the strategies and methods for self-determined, self-paced and personalised instruction to cope with the e-instructor competencies.

\section{References}

Al-Hunaiyyan, A., Al-Sharhan, S., \& Al-Sharhan, H. (2012). A new instructional competency model: towards an effective e-learning system and environment. International Journal of Information Technology \& Computer Science, 5, 94-103.

Al-Salman, S. M. (2011). Faculty in online learning programs: Competencies and barriers to success. Journal of Applied Learning Technology, 1(4), 6-13.

Anderson, M. A. (2010). What's it like to teach an online class? MultiMedia \& Internet @ Schools, 17(6), 20-23.

ASTD (2013).The ASTD competency model. Retrieved on 15 May 2013 from http://www.astd. org/Certification/Competency-Model

Awouters, V., \& Jans, S. (2009). E-learning competencies for teachers in secondary and higher education. iJet, 4(2), 58-60.

Barker, P. (2002). On Being an Online Tutor. Innovations in Education and Teaching International, 39(1), 3-13.

Bawanea, J., \& Spector, J. M. (2009). Prioritization of online instructor roles: implications for competency-based teacher education programs. Distance Education, 30(3), 383-397.

Berge, Z. L. (1995). The role of the online instructor/facilitator. Educational Technology, 35(1), 22-30.

Bremer, C. (2010). Fit for e-learning? Trainings for e-learning competencies. Retrieved on 15 May 2013 from http://www.studiumdigitale.uni-frankfurt.de/veroeffentlichungen/ documents/edulearn2010_1.pdf

Burkle, M., \& Cleveland-Innes, M. (2013).Defining the role adjustment profile of learners and instructors online. Journal of Asynchronous Learning Networks, 17(1), 73-87. 
Coppola, W. N., Hiltz, R., \& Rotter, N. (2002). Becoming a virtual professor: pedagogical roles and asynchronous learning networks. Journal of Management Information Systems, 18(4), 169-189.

Davis, N., Roblyer, M. D. P. , Charania, A., Ferdig, R., Harms, C., Compton, L. K. L., \& Cho, M. O. (2007). Illustrating the "virtual" in virtual schooling: Challenges and strategies for creating real tools to prepare virtual teachers. Internet and Higher Education, 10, 27-39.

Dennis, B., Watland, P., Pirotte, S., \& Verday, N. (2004). Role and competencies of the e-tutor. Proceedings of the Networked Learning Conference 2004. Retrieved on 15 May 2013 from http://www.networkedlearningconference.org.uk/past/nlc2004/proceedings/ symposia/symposium6/denis_et_al.htm.

Goold, A., Coldwell, J., \& Craig, A. (2010). An examination of the role of the e-tutor. Australasian Journal of Educational Technology, 26(5), 704-716.

Guasch, T, Alvarez, I., \& Espasa, A. (2010). University teacher competencies in a virtual teaching/learning environment: Analysis of a teacher training experience. Teaching and Teacher Education, 26, 199-206.

Guldberg, K., \& Pilkington, R. (2007). Tutor roles in facilitating reflection on practice through online discussion. Educational Technology \& Society, 10(1), 61-72.

Hartel, R. W., \& Foegeding, E. A. (2004). Learning: Objectives, competencies, or outcomes? Journal of Food Science Education, 3(4), 69-70.

Kelz, A. (2011). Bridging the gap - From teacher to eTeacher. Proceedings of the 10th European Conference on e-Learning (pp. 363-369).

Klein, J. D., Spector, J. M., Grabowski, B., \& de la Teja, I. (2004). Instructor competencies: Standards for face-to-face, online, and blended settings. Retrieved on 15 May 2013 from http://www.tutzauer.com/TLC/Teaching_competencies.pdf.

Levinsen, K. T. (2007). Qualifying online teachers-Communicative skills and their impact on elearning quality, Education and Information Technology, 12(1) 41-51.

Liu, X., Bonk, C. J., Magiuka, R. J., Lee, S., \& Su, B. (2005). Exploring four dimensions of online instructor roles: A program level case study. Journal of Asynchronous Learning Networks, 9(4), 29-48.

Mishra, P., \& Koehler, M. (2006). Technological pedagogical content knowledge: A framework for teacher knowledge. Teacher College Record, 108(6), 1017-1054.

Misra, P. K. (2010).Preparing e-excellent teachers for the world of E-education: potential strategies. i-manager's Journal of Educational Technology, 7(3), 21-29.

Palloff, R. M. \& Pratt, K. (2011). The excellent online instructor: Strategies for professional development. New York: John Wiley \& Sons.

Queiroz, V. (2003). Roles and competencies of online teachers. The Internet TESL Journal, 9(7). Retrieved on 15 May 2013 from http://iteslj.org/Articles/Queiroz-OnlineTeachers.html.

Richey, R.C., Fields, D.C., Foxon, M., Roberts, R.C., Spannaus, T., \& Spector, J.M. (2001). Instructional design competencies: The standards (3rd ed.) Retrieved on 15 May 2013 from htttp://www.eric.ed.gov/PDFS/ED453803.pdf. 
Shank, P. (2004). Competencies for online instructors. Retrieved on 15 May 2013 from http://www.mnsu.edu/cetl/teachingwithtechnology/tech_resources_pdf/Competencies \%20for\%200nline\%20Instructors.pdf.

Shulman, L. (1986). Those who understand: Knowledge growth in teaching. Educational Researcher, 15(2), 4-14.

SLOAN-C. (2012). SLOAN-C Online Teaching Certificate. Retrieved on 15 May 2013 from http://sloanconsortium.org/institute/certificate-program.

Smith, T. C. (2005). Fifty-one competencies for online instruction. The Journal of Educators Online, 2(2), 1-18.

Spector, J. M., \& de la Teja, I. (2001). Competencies for online teaching. ERIC Digest. ERIC Clearinghouse on Information and Technology. Syracuse: NY. Retrieved on 15 May 2013 from http://www.eric.ed.gov/PDFS/ED456841.pdf.

UNESCO. (2011). ICT Competency Framework for Teachers. Retrieved on 15 May 2013 from http://unesdoc.unesco.org/images/0021/002134/213475E.pdf

University of Wisconsin La Crosse (2009). Learning outcomes handbook. Retrieved on 15 May 2013 from http://www.uwlax.edu/learningoutcomes/resources/ LearningOutcomesHandbook.pdf.

Williams, P. E. (2003). Roles and competences for distance education programs in higher institutions. American Journal Education, 17, 45-57.

Yar, C. Y., Asmuni, A., \& Silong, A. D. (2008). Roles and Competencies of Distance Education Tutors in a Public University. Malaysian Journal of Distance Education, 10(1), 21-39.

Correspondence: Filiz Kalelioglu, Department of Computer Education and Instructional Technologies, Faculty of Education, Baskent University, Ankara, Turkey 